\title{
PERAN SITUS DAN TRADISI RITUAL KEAGAMAAN di Pulau-Pulau Kecil di Jepara
}

\author{
Achmad Sahri \\ Perencanaan dan Pengelolaan Sumber Daya Kelautan \\ Magister Manajemen Sumber Daya Pantai Universitas Diponegoro
}

\begin{abstract}
Jepara Regency possesses 29 small islands; two islands are located near the mainland, these are Pulau Panjang and Pulau Mandalika. Both those islands having religious sites such as ulama graves and religious ritual traditions retained by surrounding society. The existence of religious sites and ritual traditions of these islands is effective in maintaining existing natural resources against the overexploitation, thus damages of natural resources can be avoided.
\end{abstract}

Key words: Jepara, small islands, religius tradition, ulama garve, natural resource.

\section{Pendahuluan}

Kasus hilangnya pulau, gosong dan karang di Indonesia semakin sering terjadi pada beberapa dekade terakhir ini. Penyebab dari hilangnya pulau ini dapat berasal dari faktor alam seperti kenaikan muka air laut (sea level rise) akibat pemanasan global (global warming), maupun akibat yang disebabkan oleh aktivitas manusia (antrophogenic factor) seperti kegiatan penambangan pasir atau karang di pulau. Hilangnya karang juga terjadi di Kabupaten Jepara, yaitu Karang Bokor, yang secara administratif terletak di Kecamatan Kedung, pada jarak sekitar 2 (dua) km ke arah barat dari garis pantai. Hilangnya karang ini diduga akibat ditambang oleh nelayan Demak dan Jepara yang memanfaatkan karang ini sebagai bahan bangunan untuk mendirikan rumah mereka. Peta Topografi tahun 1944 yang dikeluarkan oleh Dinas Topografi KODAM IV Diponegoro menunjukkan bahwa karang ini masih ada, namun pada Peta Rupabumi tahun 2001 yang dipublikasikan oleh Badan Koordinasi Survei dan Pemetaan Nasional (BAKOSURTANAL), karang ini sudah tidak ada lagi, karena sudah hilang. Hilangnya karang ini dibuktikan dengan kenampakan citra satelit Landsat ETM+ tahun 2003, di 
mana pada lokasi tersebut terlihat rona agak cerah, yang menandakan bahwa di daerah tersebut dulunya terdapat kenampakan alam berupa karang.

Berbeda halnya dengan dua pulau lainnya yang dimiliki Kabupaten Jepara, yaitu Pulau Panjang dan Pulau Mandalika yang tetap ada sampai sekarang. Setidaknya ada tiga penyebab mengapa kedua pulau ini tetap ada, sebagai berikut.

Pertama, letak kedua pulau tersebut lebih dekat dengan pusat pemerintahan. Pulau Panjang terletak di Kecamatan Jepara yang menjadi pusat pemerintahan dari Kabupaten Jepara dan berjarak hanya 1,65 km. Demikian juga dengan Pulau Mandalika, dekat dengan Kecamatan Keling, yang menjadi pusat pemerintahan Kabupaten Jepara bagian utara, serta dekat dengan situs pemerintahan yang sudah lama berdiri di sana berupa benteng pertahanan militer yang disebut "Benteng Portugis," yaitu sekitar 1,96 km (Diskanlut Prov. Jateng, 2008; DKP, 2006). Sedangkan Karang Bokor terletak dekat dengan daerah perbatasan antara Kabupaten Jepara dengan Kabupaten Demak. Letaknya yang diperbatasan inilah yang mungkin menjadikan masyarakat di sekitarnya berlombalomba untuk menambang karang tersebut, karena keduanya merasa berhak memiliki, sehingga pada akhirnya karang tersebut habis karena ditambang. Kedua, Pulau Panjang dan Pulau Mandalika lebih luas (masing-masing 22,20 ha dan 14,49 ha) dibandingkan dengan Karang Bokor (hanya sekitar 3,10 ha) (Diskanlut Prov. Jateng, 2008; DKP, 2006). Pulau/karang yang relatif luas membuat masyarakat berfikir ulang untuk melakukan penambangan berlebih, apalagi sampai menyebabkan pulau tersebut hilang. Ketiga, di dalam pulau kecil tersebut terdapat situs dan ritual tertentu yang menjadikan masyarakat tetap memelihara eksistensi pulau sampai sekarang.

Tulisan ini membahas mengenai peran situs dan ritual yang ada di pulau-pulau kecil di Jepara, yaitu Pulau Panjang dan Pulau Mandalika, dalam mendukung eksistensi dan fungsinya dalam mengendalikan kegiatan eksploitasi berlebihan (over exploitation) sumberdaya alam yang ada di pulau tersebut.

\section{Kondisi Fisik Pulau-Pulau Kecil di Jepara}

\section{1. Pulau Panjang}

Pulau Panjang secara geografis terletak pada koordinat $110^{\circ} 37^{\prime} 30^{\prime \prime}-110^{\circ} 37^{\prime} 50^{\prime \prime}$ BT dan $6^{\circ} 34$ ' 25" - $6^{\circ} 34$ ' 40" LS. Secara administrasi, pulau ini termasuk dalam wilayah Kecamatan Jepara, Kabupaten Jepara. Pulau ini berjarak sekitar 1,65 km sebelah 
barat Pantai Kartini, atau sekitar 4 km dari Pusat Kota Jepara (Diskanlut Prov. Jateng, 2008).

Luas daratan Pulau Panjang berdasarkan citra Aster tahun 2006 seluas 22,2 ha dengan panjang garis pantai 2,2 km. Pulau ini dikelilingi terumbu karang seluas 20,3 ha. Pulau ini tidak berpenghuni tetap dan hanya dimanfaatkan sebagai kawasan pariwisata dan perkebunan kelapa (FPIK UNDIP, 2006).

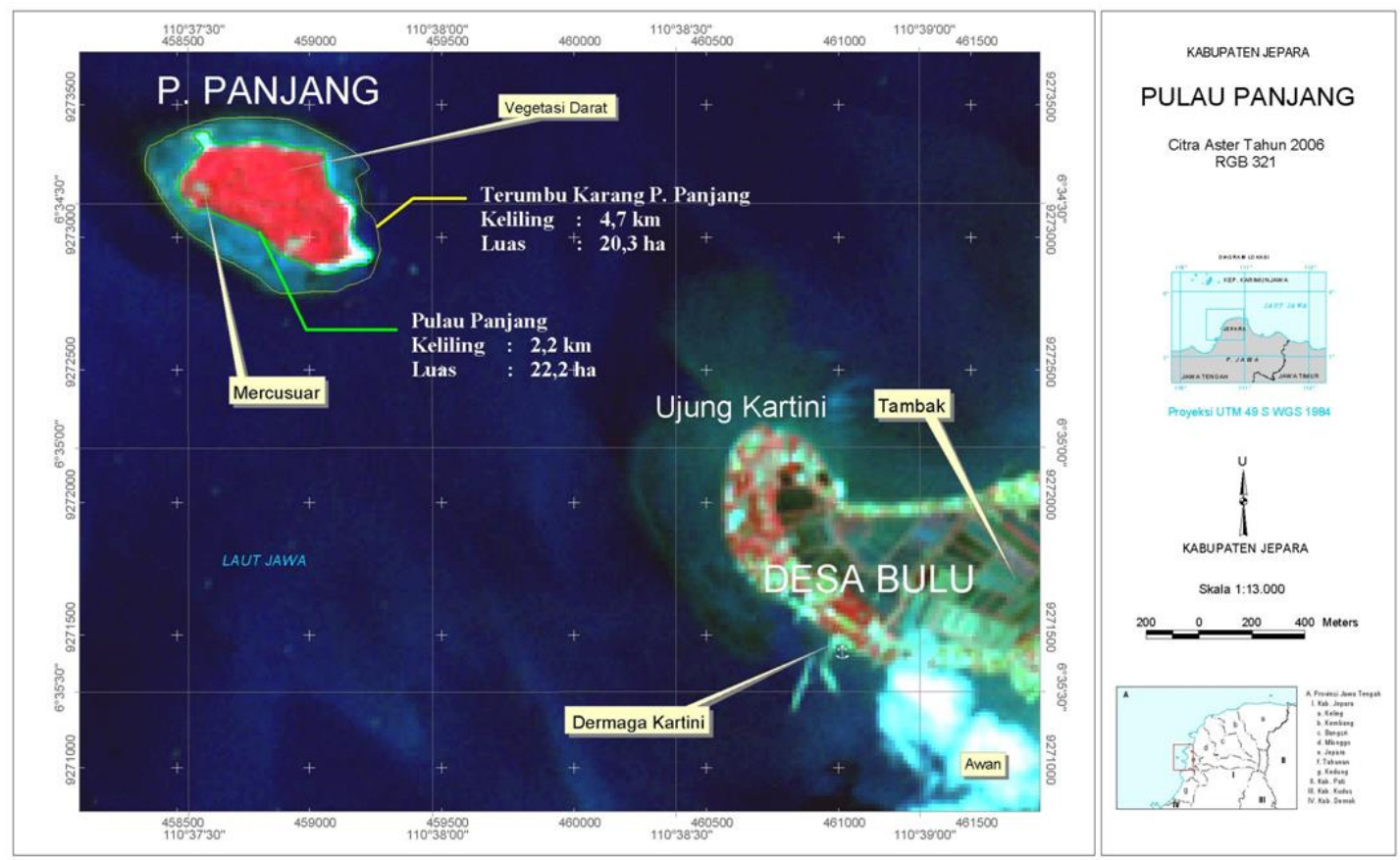

Gambar 1: Peta Citra Satelit Aster Pulau Panjang, Kabupaten Jepara.

Selain dikelilingi oleh terumbu karang, pulau ini juga memiliki daerah padang lamun cukup luas dengan kedalaman yang bervariasi (Diskanlut Prov. Jateng, 2008). Kondisi perairan di pulau ini masih cukup baik. Namun demikian, kegiatan pariwisata yang akhir-akhir ini dilaksanakan oleh masyarakat dalam intensitas yang cukup besar, dikhawatirkan dapat memicu degradasi lingkungan, jika tidak ada peraturan yang jelas dan pengawasan yang tegas untuk menjaga kelestarian lingkungan.

Beberapa sarana dan prasarana yang ada di Pulau Panjang antara lain jalan, sarana air tawar, mercusuar dan sarana transportasi. Jalan merupakan sarana yang vital dalam menunjang aksesibilitas di suatu daerah. Di Pulau Panjang terdapat jalan sepanjang pantai mengelilingi pulau. Sumur air tawar terletak di sebelah selatan pulau yang dapat dimanfaatkan oleh pengunjung. Kondisi vegetasi yang terjaga di Pulau Panjang dapat mendukung keberadaan air tawar di pulau tersebut (Diskanlut Prov. Jateng, 2008). 
Mercusuar terdapat di sisi sebelah barat pulau yang berfungsi sebagai tanda bagi kapalkapal yang melintas di sekitar perairan Pulau Panjang.

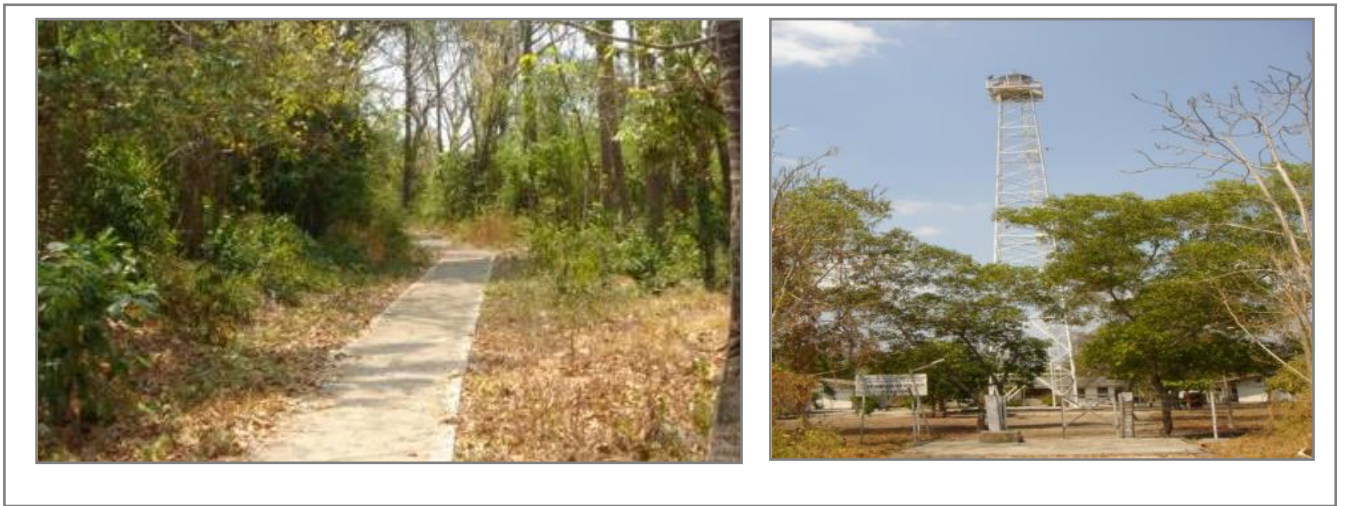

Gambar 2: Sarana dan prasarana yang terdapat di Pulau Panjang, antara lain berupa jalan dan mercusuar.

Fasilitas transportasi untuk menuju Pulau Panjang mudah untuk didapatkan, banyak kapal nelayan, disebut sopek, terdapat di Pantai Jepara yang dapat disewa untuk menuju ke Pulau Panjang karena jarak tempuh yang relatif dekat yaitu sekitar 1,65 km dari Pantai Kartini Jepara (Diskanlut Prov. Jateng, 2008).

Masalah yang cukup serius yang dihadapi Pulau Panjang adalah tingkat abrasi yang cukup besar, baik secara alami maupun karena perbuatan manusia. Secara alami, gempuran ombak yang besar menyebabkan beberapa sisi pulau terutama yang berhadapan dengan Laut Jawa, mengalami abrasi. Aktivitas penambangan pasir pantai dan karang mati yang dilakukan oleh penduduk yang tinggal dekat dengan pulau juga mempercepat proses abrasi. Karang mati tersebut banyak digunakan oleh penduduk setempat sebagai bahan bangunan. Penambangan yang tidak terkendali telah menyebabkan abrasi pantai, karena salah satu fungsi karang mati adalah sebagai penahan gelombang yang efektif, mengingat komposisi penyusunnya yang masif (Bappeda Jepara, 2003).

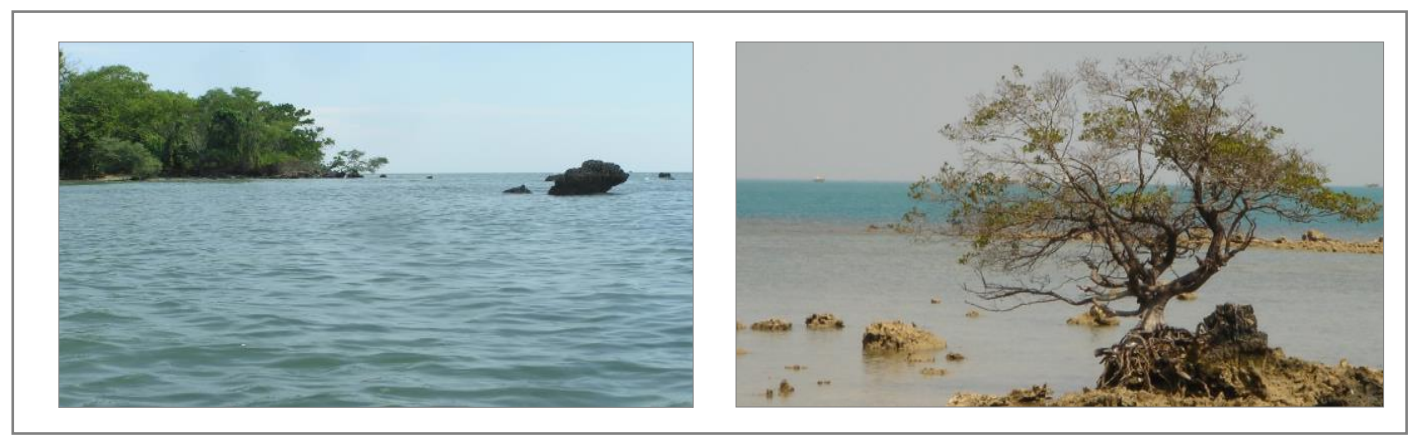


Gambar 3: Sisi barat Pulau Panjang yang terkena abrasi.

\section{2. Pulau Mandalika}

Pulau Mandalika adalah salah satu pulau kecil yang terdapat di Kabupaten Jepara dan secara administrasi termasuk dalam wilayah Desa Ujungwatu, Kecamatan Keling, Kabupaten Jepara. Secara geografis, Pulau Mandalika berada pada koordinat $110^{\circ} 55^{\prime} 8^{\prime \prime}$ $110^{\circ} 55^{\prime} 25^{\prime \prime} \mathrm{BT}$ dan $06^{\circ} 22^{\prime} 49^{\prime \prime}-06^{\circ} 23^{\prime} 6^{\prime \prime}$ LS. Pulau ini terletak kurang lebih 1,96 km dari daratan Pulau Jawa, pada daerah perbatasan Kabupaten Jepara dan Kabupaten Pati. Pulau Mandalika mempunyai garis pantai $\pm 1,58 \mathrm{~km}$ dengan luas wilayah daratan sekitar 14,5 hektar. Dari pusat kota kecamatan, pulau ini dapat dijangkau melalui perjalanan darat dengan menempuh jarak $12 \mathrm{~km}$, sedangkan dari pusat Kota Jepara berjarak 51 (lima puluh satu) km (DKP, 2006).

Pada zaman penjajahan, wilayah daratan Pulau Mandalika dikuasai oleh Belanda. Untuk kepentingan keamanan laut, pada tahun 1897 dibangun mercusuar di puncak Pulau Mandalika beserta 4 buah bangunan tua yang berfungsi untuk mendukung kegiatan pengoperasian mercusuar. Setelah zaman kemerdekaan, pulau ini dikelola oleh Dinas Perhubungan, sementara wilayah perairannya menjadi kewenangan Pemerintah Kabupaten Jepara berdasarkan UU No. 32 tahun 2004 tentang Pemerintahan Daerah. Pada bagian puncak pulau pada luasan sekitar 1 ha, saat ini telah dibangun 4 (empat) rumah pegawai Dinas Perhubungan beserta 2 buah diesel. Di wilayah pesisir pulau terdapat sebuah gudang penampungan solar berukuran $3 \mathrm{~m}$ x $5 \mathrm{~m}$ serta rumah dan mesin pengoperasian mercusuar berukuran $9 \mathrm{~m}$ x $15 \mathrm{~m}$ (DKP, 2006). 


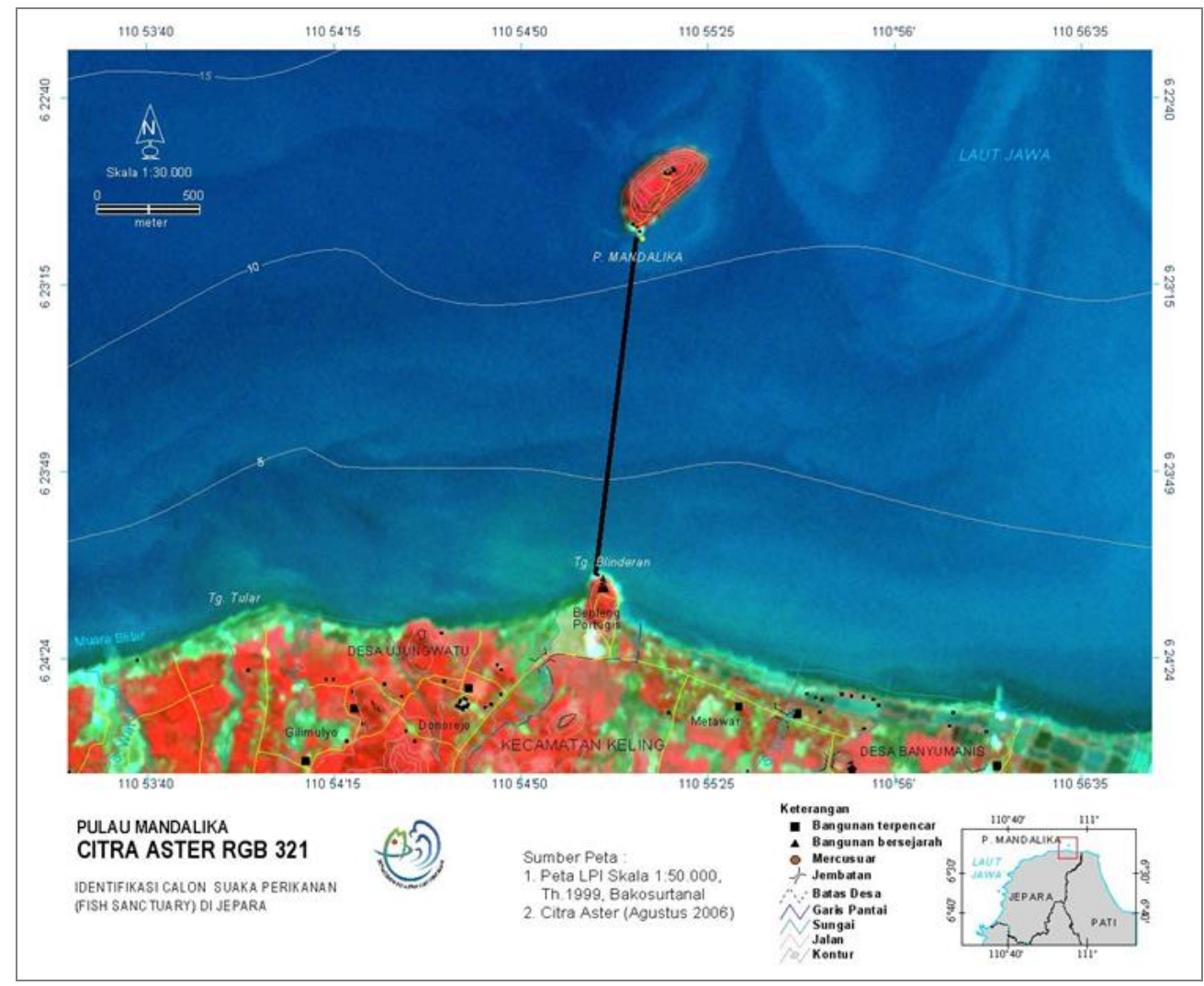

Gambar 4: Peta Citra Satelit Aster Pulau Mandalika, Kabupaten Jepara.

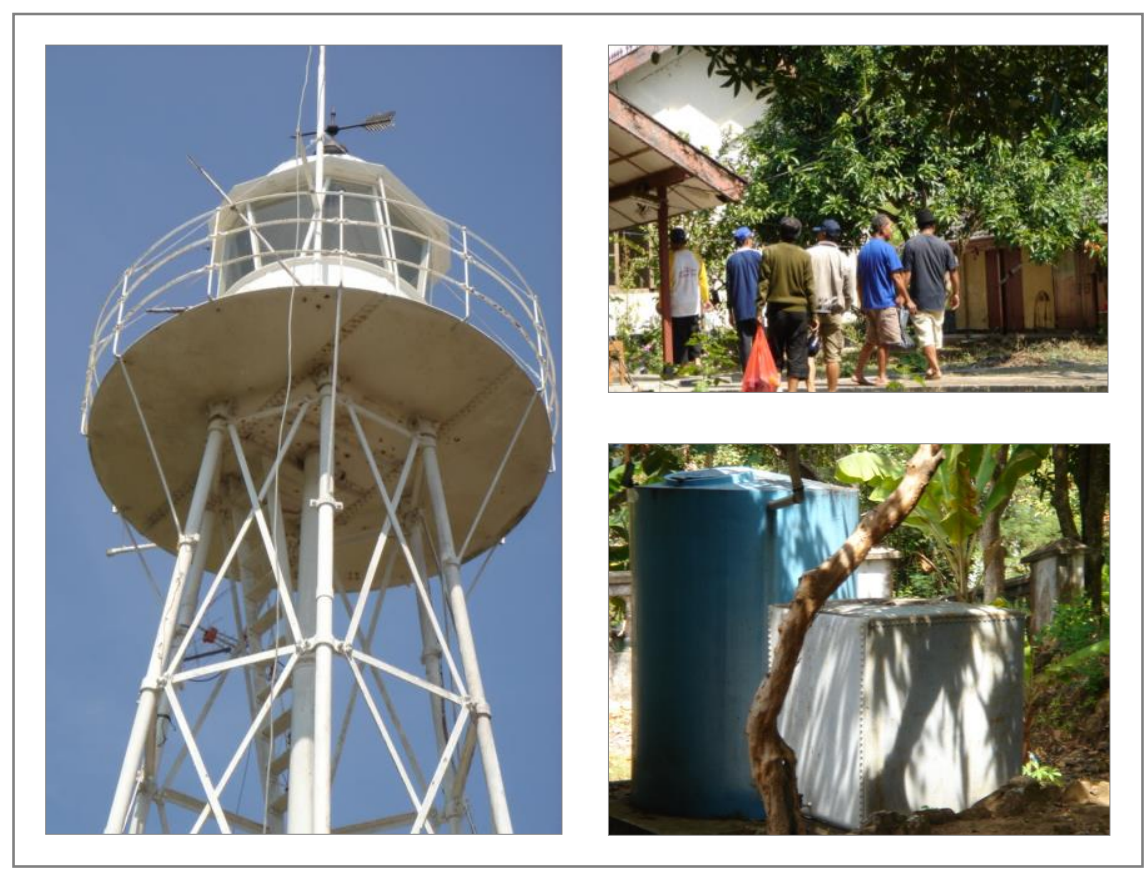

Gambar 5: Beberapa sarana dan prasarana yang ada di Pulau Mandalika berupa mercusuar (kiri); rumah dinas penjaga mercusuar (kanan atas); dan tandon air (kanan bawah). 
Sebagian besar wilayah daratan Pulau Mandalika ditumbuhi oleh pohon kepoh, asam dan randu alas, sedangkan bagian bawah pohon, pada tanah yang terbuka banyak ditumbuhi oleh semak-semak seperti tanaman gadung, sejenis talas. Oleh penjaga mercusuar, lahan dekat perumahan dinas telah ditanami tanaman produksi seperti mangga, rambutan, blimbing dan pisang (DKP, 2006).

Walaupun merupakan pulau kecil, Pulau Mandalika memiliki ketinggian yang bervariasi dengan titik tertinggi $85 \mathrm{~m}$ di atas permukaan laut. Berdasarkan kondisi morfologinya, wilayah Pulau Mandalika merupakan dataran berbukit dengan kemiringan $15-45 \%$ (DKP, 2006).

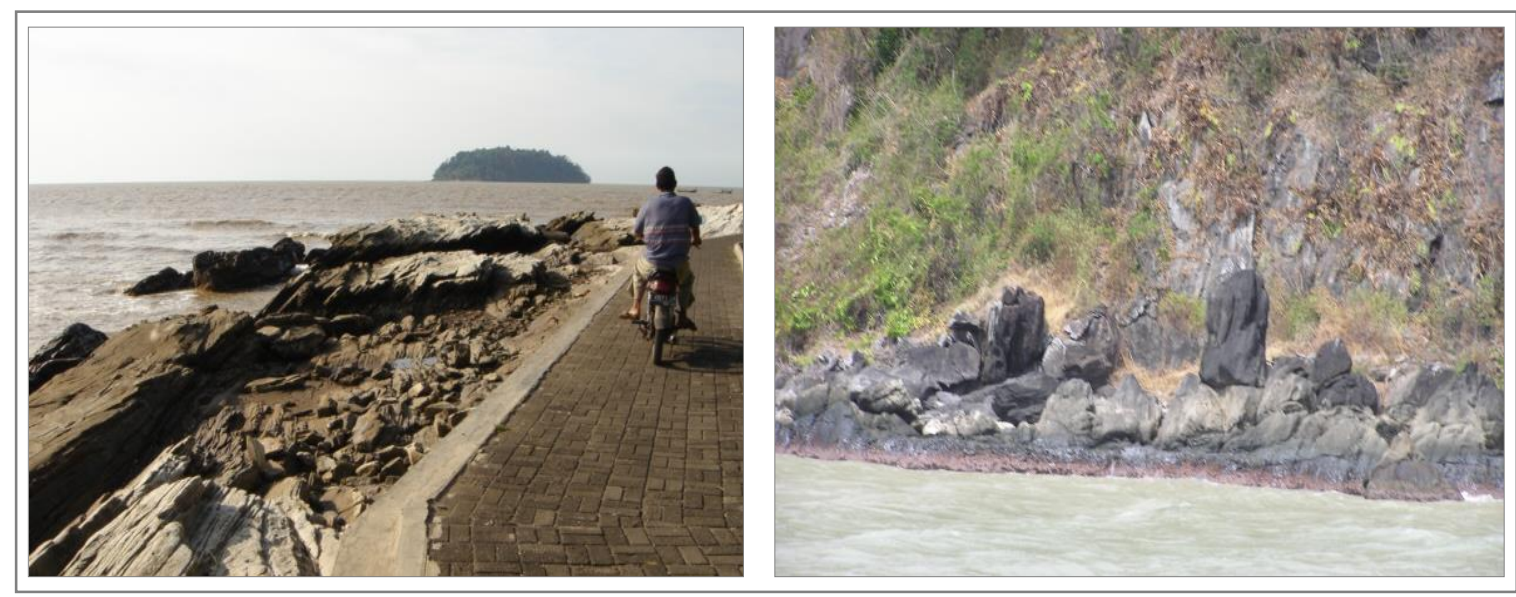

Gambar 6: Tampak Pulau Mandalika dari Benteng Portugis (kiri) dan topografi pulau yang terjal (kanan).

Perairan sekitar Pulau Mandalika merupakan perairan yang relatif dangkal dengan kedalaman antara 4-10 m. Namun demikian, landaian dasar perairan laut yang berfluktuasi cukup besar ditemui di antara sisi pulau yang berbeda. Pada bagian selatan pulau yang berhadapan dengan daratan Pulau Jawa, kondisi dasar perairannya relatif landai, sedangkan pada sisi pulau yang lain kondisinya curam, terutama pada sisi barat daya pulau yang biasa disebut sebagai "Watu Gedeg" (DKP, 2006).

Substrat dasar perairan di sekeliling Pulau Mandalika didominasi oleh substrat batu yang tertutupi oleh endapan lumpur (DKP, 2006). Formasi substrat dasar bebatuan tahan terhadap gempuran gelombang dan ombak, sehingga tetap dapat mempertahankan bentuk pantai dan kekokohan pulau. Dengan substrat dasar berupa batu inilah, pulau kecil ini dapat tetap bertahan di tengah perairan Laut Jawa. 


\section{Kondisi Sosial Budaya Masyarakat Sekitar Pulau}

Pulau Panjang dan Pulau Mandalika merupakan pulau kecil yang boleh dikatakan tak berpenghuni. Masyarakat yang tinggal di sekitar pulau tersebut yang mewarnai kondisi pulau-pulau kecil tersebut. Kehidupan sosial budaya masyarakat Kabupaten Jepara yang tinggal di sekitar dua pulau tersebut pada umumnya sama seperti kondisi sosial budaya masyarakat pesisir/pantai lainnya, yang dicirikan dengan masyarakat yang agamis, namun masih percaya pada hal-hal yang bersifat mistis.

Perilaku masyarakat Kabupaten Jepara secara umum merupakan perpaduan dari masyarakat perkotaan dan pedesaan. Perilaku masyarakat perkotaan dicirikan dengan pandangan masyarakat yang terbuka dan berwawasan luas, sedangkan perilaku masyarakat pedesaan lebih bersifat homogen dan mempertahankan adat istiadat yang bersifat tradisional. Masyarakat dengan kultur pedesaan ini, terutama ditemukan di wilayah pinggiran, seperti masyarakat yang dekat dengan Pulau Mandalika, namun tidak bagi masyarakat yang tinggal di sekitar Pulau Panjang, karena Pulau Panjang terletak dekat dengan Kota Jepara (Pemda Jepara, 1994).

Kondisi sosial budaya masyarakat Kabupaten Jepara selain merupakan perpaduan perilaku masyarakat pedesaan dan perkotaan, juga mendapat pengaruh sosial budaya dari luar negeri, terutama dari para investor pendatang bangsa-bangsa barat seperti dari Eropa Barat, Amerika Serikat, dan Australia. Pengaruh budaya barat tersebut muncul karena beberapa warga negara asing yang melakukan usaha permeubelan di Kabupaten Jepara pun membawa serta gaya hidup dan kebiasaan-kebiasaannya . Karakteristik sosial budaya lainnya yang juga ditemukan dalam masyarakat Jepara adalah terdapatnya tatanan kehidupan kelas buruh dan kelas pengusaha. Hal ini tercipta karena berkembangnya sektor industri terutama kerajinan kayu dan meubel di wilayah Jepara (Pemda Jepara, 1994).

Nilai sosial budaya masyarakat pedesaan di Jepara yang bersifat positif antara lain gotong royong, musyawarah, dan peran aktif dalam kegiatan keagamaan. Semua kegiatan tersebut merupakan akar budaya yang menjadi tuntunan dalam kehidupan bermasyarakat. Aktivitas sosial budaya yang masih dilestarikan dan merupakan ciri khas masyarakat daerah pantai adalah upacara sedekah laut yang dilaksanakan setiap tahun sekali pada saat tertentu dan biasanya dilakukan berkaitan dengan hari besar agama Islam. Tradisi sedekah laut tersebut merupakan tradisi yang dapat dijumpai di wilayah-wilayah pantai di 
Pulau Jawa, baik pantai utara maupun pantai selatan. Selain itu, kepercayaan masyarakat terhadap sesuatu yang berbau mistis masih kental terasa, seperti nelayan yang tidak melakukan operasi penangkapan bila tiba hari-hari tertentu yang dianggap sebagai hari pantangan (Pemda Jepara, 1994).

\section{Situs dan Ritual Keagamaan di}

\section{1. Situs dan Ritual Keagamaan di Pulau Panjang}

Pulau Panjang memiliki satu situs keagamaan yang sudah lama dikenal oleh masyarakat dan sampai sekarang masih dipertahankan yaitu makam Syeh Abu Bakar. Menurut cerita yang beredar dalam masyarakat, Syeh Abu Bakar adalah ulama yang mengajarkan agama islam di sekitar daerah Jepara yang hidup setelah jaman Wali Songo (Wali Sembilan). Selain makam, tidak jauh dari lokasi tersebut berdiri fasilitas peribadatan berupa sebuah masjid, yang digunakan sebagai fasilitas ibadah bagi para peziarah yang datang ke makam Syeh Abu Bakar (Dispar Jepara, 2000).

Ritual keagamaan yang ada di Pulau Panjang yang tergolong besar dan bersifat tahunan ada 2 (dua), yaitu kegiatan Suronan dan Syawalan. Kegiatan Suronan diselenggarakan pada bulan Syuro (kalender Jawa) pada hari pasaran wage pertama dari bulan tersebut; sedangkan kegiatan Syawalan dilaksanakan pada hari ke-7 hari raya Idul Fitri. Kegiatan yang dilaksanakan berupa syukuran dan tahlilan bersama di sekitar makam. Selain kedua ritual besar tersebut, juga dilaksanakan kegiatan ritual dalam skala yang lebih kecil, yaitu setiap hari Kamis wage sore (menjelang Jum'at Kliwon) setiap bulan (Dispar Jepara, 2000).

\section{2. Situs dan Ritual Keagamaan di Pulau Mandalika}

Situs keagamaan yang ada di Pulau Mandalika, sama dengan yang ada di Pulau Panjang yaitu berupa makam ulama setempat yang hidup pada masa yang lalu, yaitu Sayyid Usman. Makam ini terletak di pinggir pantai yang bertanah datar, mengingat topografi pulau ini sebagian besar berupa daratan berbukit. Di sekeliling makam dipugar rumah kecil yang berfungsi sebagai tempat kunjungan bagi para peziarah ke makam tersebut (Pemda Jepara, 2003).

Berbeda dari yang ada di Pulau Panjang, ritual keagamaan di Pulau Mandalika yang tergolong besar hanya dilakukan sekali dalam setahun, yaitu pada saat ulang tahun kematian Sayyid Usman atau yang biasa disebut sebagai "khaul." Sementara ritual yang berskala kecil dilakukan jika ada kunjungan para peziarah ke makam tersebut, seperti 
calon kepala desa yang akan dipilih dalam pemilihan kepala desa. Ada mitos yang berkembang yang berhubungan dengan makam Sayyid Usman, yaitu bahwa peziarah yang datang ke makam tersebut dilarang berpakaian dinas atau berseragam pemerintah, karena akan berakibat kehilangan jabatan setelah berziarah ke makam tersebut (Pemda Jepara, 2003).

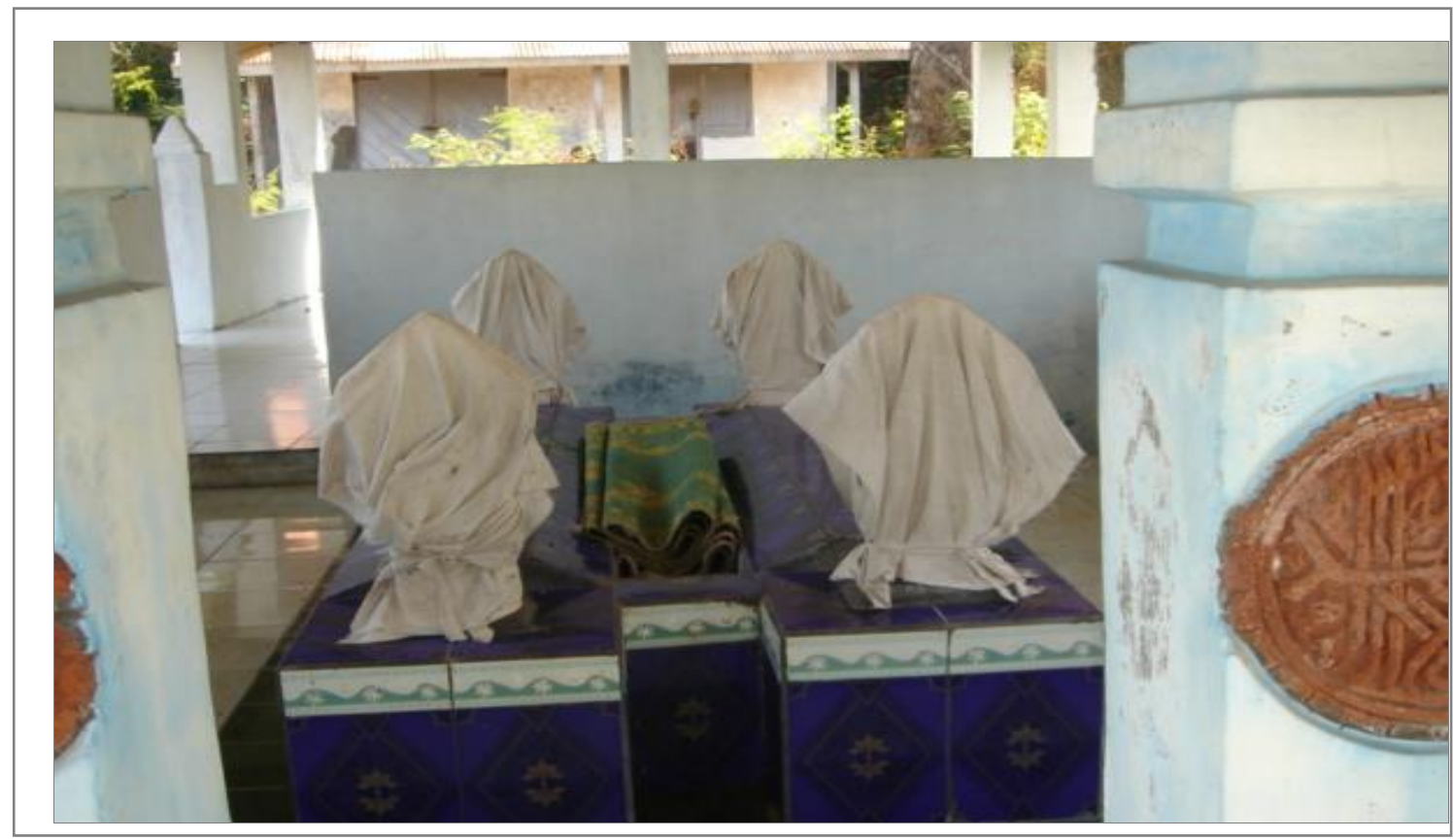

Gambar 7: Makam Sayyid Usman di Pulau Mandalika.

\section{Peran Situs dan Ritual Keagamaan di Pulau-Pulau Kecil}

Keberadaan situs keagamaan di pulau-pulau kecil dengan kultur masyarakat di sekitarnya yang masih mempercayai adanya tradisi dan ritual keagamaan sedikit banyak dapat memberikan pengaruh terhadap eksistensi pulau. Situs keagamaan seperti makam ulama merupakan syarat utama sebagai "pengendali" kegiatan over-eksploitasi sumberdaya alam oleh masyarakat, seperti penambangan pasir atau karang; pengendalian tersebut pada gilirannya dapat menyelamatkan pulau dari kerusakan dan kehilangan sumberdaya alam. Sementara tradisi ritual keagamaan seperti peringatan kematian bagi "yang dimakamkan" merupakan media pengingat kepada masyarakat bahwa pulau tersebut menyimpan tradisi budaya yang perlu dipertahankan dan dilestarikan.

Adanya makam ulama besar yaitu Syeh Abu Bakar di Pulau Panjang dan Sayyid Usman di Pulau Mandalika membuat penduduk atau pendatang tidak berani berbuat tidak 
baik ketika memasuki pulau atau berada di sekitar kawasan tersebut. Secara kultural, masyarakat yang tinggal di sekitar pulau-pulau kecil yang memiliki situs berupa makam biasanya memandang wilayah tersebut sebagai wilayah yang cukup berwibawa, atau bahkan angker, sehingga masyarakat sekitar dan para peziarah pendatang berusaha untuk menjaga tindakan dan perkataan mereka agar tidak membuat kerusakan di kawasan tersebut. Jangankan untuk merusak alam, untuk berkata tidak baik pun mereka pada umumnya sangat berhati-hati, atau bahkan tidak berani.

Kondisi seperti ini tentu sangat menguntungkan apabila kemudian pulau-pulau kecil tersebut dikelola menjadi wilayah konservasi, sehingga titik-titik wilayah penting di dalamnya dapat ditetapkan zona-zona tertentu yang melarang masyarakat untuk melakukan kegiatan-kegiatan yang tidak dikehendaki, yang bersifat merusak lingkungan dan sumber daya alam di zona tersebut. Pengakuan masyarakat akan adanya situs dan ritual keagamaan di pulau kecil yang patut dilestarikan akan dapat mengurangi biaya sosial dan mengurangi kemungkinan gesekan dan masalah dengan masyarakat akibat penetapan wilayah tersebut menjadi zona konservasi yang membutuhkan biaya dan tenaga yang tidak sedikit. Dengan demikian, maka eksistensi pulau kecil dapat dipertahankan. Wilayah-wilayah zona konservasi tersebut juga potensial untuk pengembangan pariwisata, khususnya wisata ziarah atau wisata religi dan wisata lingkungan alam atau ekowisata, dengan dukungan wisata air antar pulau.

\section{Simpulan}

Tidak dapat dipungkiri bahwa keberadaan situs-situs keagamaan berupa makam para penyebar agama Islam dan ritual ziarah di pulau-pulau kecil seperti Pulau Panjang dan Pulau Mandalika di wilayah Kabupaten Jepara dapat mengendalikan dan mempertahankan lingkungan dan saujana pulau. Keberadaan makam ulama besar yaitu Syeh Abu Bakar di Pulau Panjang dan Sayyid Usman di Pulau Mandalika berperan cukup efektif dalam menjaga dan mengendalikan berbagai sumberdaya alam di pulau-pulau kecil tersebut, sehingga kegiatan eksploitasi yang berlebihan terhadap sumberdaya alam dapat dihindari, dan kelestarian pulau dapat dipertahankan. Sumberdaya spiritual keagamaan menjadi sumbangan yang berarti dalam menjaga sumberdaya alam sekaligus mengandung potensi untuk pengembangan pariwisata khususnya wisata ziarah, wisata lingkungan, dan wisata air. 


\section{DAFTAR PUSTAKA}

Badan Perencanaan Pembangunan Daerah Jepara (Bappeda Jepara). 2003. Potensi Kelautan Kabupaten Jepara. Laporan Studi. Jepara: Pemerintah Kabupaten Jepara.

Fakultas Perikanan dan Kelautan Universitas Diponegoro (FPIK UNDIP). 2006. Studi Pemetaan Kondisi Terumbu Karang di Perairan Pulau Panjang, Jepara. Laporan Studi. Semarang: Fakultas Perikanan dan Kelautan Universitas Diponegoro.

Dinas Pariwisata Kabupaten Dati II Jepara (Dispar Jepara). 2000. Legenda Objek Wisata Jepara. Jepara: Pemerintah Kabupaten Jepara.

DKP (Departemen Kelautan dan Perikanan). 2006. Identifikasi Calon Suaka Perikanan (Fish Sanctuary) di Jepara. Laporan Akhir. Jakarta: Departemen Kelautan dan Perikanan.

Diskanlut Prov. Jateng (Dinas Perikanan dan Kelautan Provinsi Jawa Tengah). 2008. Studi Kerusakan Habitat Pesisir di Pulau Panjang sebagai Basis Konservasi dan Pengembangan Ekowisata. Laporan Akhir. Semarang: Pemerintah Provinsi Jawa Tengah.

Pemerintah Daerah Kabupaten Jepara (Pemda Jepara). 1994. Rencana Tata Ruang Wilayah Kabupaten Dati II Jepara. Laporan Studi. Jepara: Pemerintah Kabupaten Jepara.

Pemerintah Daerah Kabupaten Jepara (Pemda Jepara). 2003. Jepara: Sejarah dan Budaya, Legenda Objek-Objek Wisata. Jepara: Pemerintah Kabupaten Jepara. 